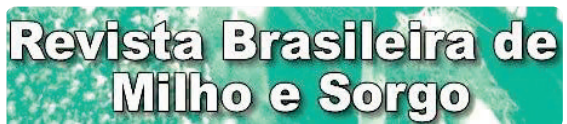

Brazilian Journal of Maize and Sorghum

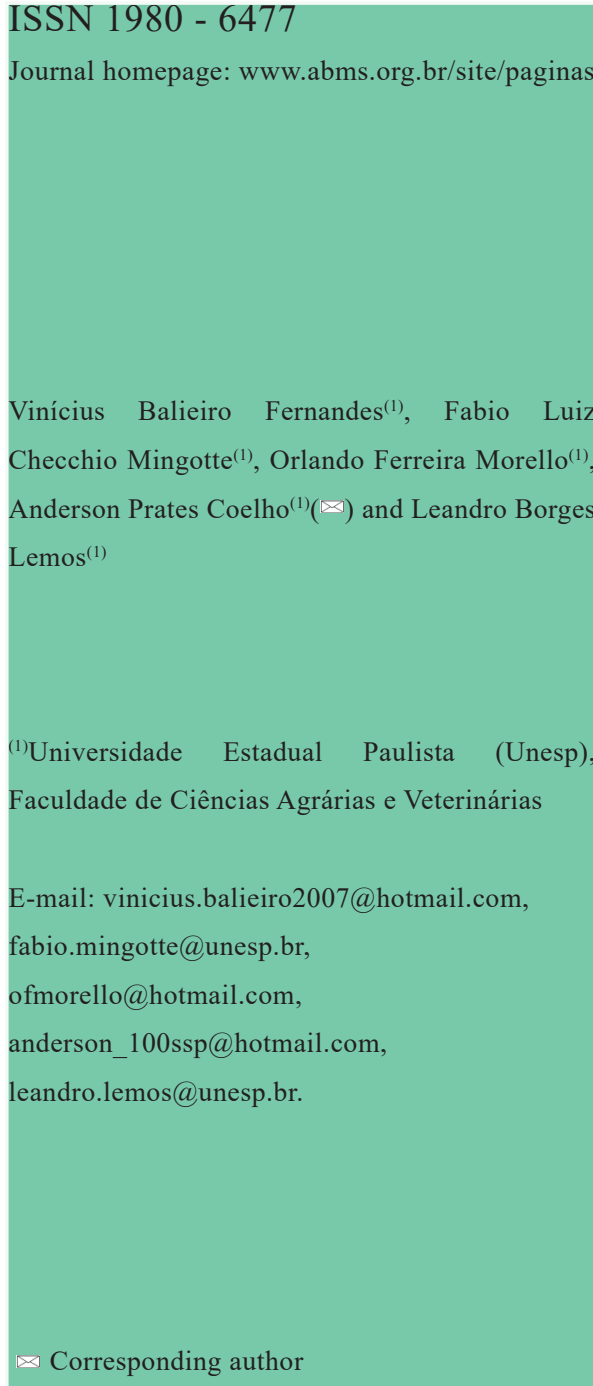

How to cite

FERNANDES, V. B.; MINGOTTE, F. L. C. MORELlO, O. F.; COELHO, A. P.; LEMOS L. B. Agronomic performance of maize under Azospirillum brasilense inoculation and topdressing nitrigen fertilization. Revista Brasileira de Milho e Sorgo, v. 19, e1185, 2020.

\section{AGRONOMIC PERFORMANCE OF MAIZE UNDER Azospirillum brasilense INOCULATION AND TOP- DRESSING NITROGEN FERTILIZATION}

\begin{abstract}
Maize inoculation with bacteria of the genus Azospirillum can reduce the consumption of nitrogen fertilizers to obtain maximum grain yield. In this context, the aim was to evaluate the effect of inoculation with Azospirillum brasilense associated with nitrogen fertilization on the maize agronomic performance. A randomized block design was used in a split-plot scheme with four replicates. Four inoculation managements with Azospirillum brasilense (T0 - control without

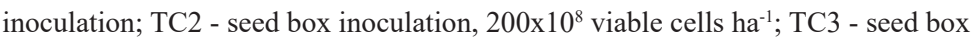
inoculation, $400 \times 10^{8}$ viable cells $\mathrm{ha}^{-1}$; TS1 - previous inoculation of the seeds, $600 \times 10^{8}$ viable cells $\left.\mathrm{ha}^{-1}\right)$ associated with four top-dressing $\mathrm{N}$ doses $(0,60,120$ and $180 \mathrm{~kg} \mathrm{ha}^{-1}$ ), applied at maize stage $\mathrm{V}_{6}$ by urea. Inoculation with Azospirillum brasilense associated with top-dressing nitrogen fertilization increases the number of grain rows per ear, number of grains per row, number of grains per ear and grain yield of maize, mainly due to its positive effects on plant nutrition. Managements with seed box inoculation with $400 \times 10^{8}$ viable cells per ha (TC3) and inoculation in seed pre-treatment (TS1) are the most recommended for maize.
\end{abstract}

Key words: Zea mays L., diazotrophic bacteria, nitrogen extraction, grain yield.

\section{DESEMPENHO AGRONÔMICO DE MILHO SOB INOCULAÇÃO COM Azospirillum brasilense E ADUBAÇÃO NITROGENADA DE COBERTURA}

\begin{abstract}
Resumo - A inoculação do milho com bactérias do gênero Azospirillum pode mitigar o consumo de fertilizantes nitrogenados para a obtenção de máximas produtividades. Neste sentido, objetivou-se avaliar o efeito da inoculação com Azospirillum brasilense associada à adubação nitrogenada em cobertura no desempenho agronômico do milho. Utilizou-se o delineamento de blocos casualizados no esquema de parcelas subdivididas, com quatro repetições. Foram utilizados quatro manejos de inoculação com Azospirillum brasilense (T0 testemunha sem inoculação; TC2 inoculação na caixa de sementes, $200 \times 10^{8}$ células

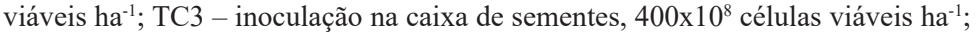
TS1 - inoculação prévia das sementes, $600 \times 10^{8}$ células viáveis ha ${ }^{-1}$ ) associadas a quatro doses de $\mathrm{N}\left(0,60,120\right.$ e $\left.180 \mathrm{~kg} \mathrm{ha}^{-1}\right)$, aplicadas no estádio $\mathrm{V}_{6}$ do milho, via ureia. A inoculação com Azospirillum brasilense associada à adubação nitrogenada em cobertura aumenta o número de fileiras de grãos por espiga, número de grãos por fileiras, número de grãos por espiga do milho e produtividade de grãos, principalmente devido seus reflexos positivos na nutrição das plantas. Os manejos de inoculação na caixa de sementes com $400 \times 10^{8}$ células viáveis por ha (TC3) e inoculação em tratamento prévio de sementes (TS1) com $600 \times 10^{8}$ células viáveis são os mais recomendados.
\end{abstract}

Palavras-chave: Zea mays L., bactéria diazotrófica, extração de nitrogênio, produtividade de grãos. 
Despite the high production potential of commercial maize hybrids available to producers (Hanashiro et al., 2013), the national average yield is on the order of only $5.1 \mathrm{t} \mathrm{ha}^{-1}$ (CONAB, 2018). Among the numerous biotic and abiotic factors that interfere in maize grain yield, nitrogen fertilization has aroused the interest of the scientific community. In this context, there is a need for sustainable technological innovations regarding the use and management of fertilizers, especially nitrogen, which are decisive in obtaining high grain yields.

Nitrogen $(\mathrm{N})$ is highly extracted by maize plants, and approximately $25 \mathrm{~kg}$ are needed for each ton of grain produced (Fornasieri Filho, 2007). The recommendations consider the expected yield, as it is directly related to plant extraction and export of $\mathrm{N}$ by grains, and history of the plot, in order to empirically predict the contribution of soil $\mathrm{N}$ together with some aspects of management (Cantarella \& Duarte, 2004). However, the definition of the period, as well as the mode of application and doses of $\mathrm{N}$ to be applied to obtain the expected yields, depends on several factors, especially the cropping system and absorption rate by plants.

Studies have indicated that biological nitrogen fixation (BNF) by Azospirillum brasilense bacteria in association with grasses (Hungria et al., 2010) can contribute to nitrogen supply, considerably meeting plant needs (Baldani et al., 1997; Martins et al., 2018). Unlike symbiotic bacteria such as Rhizobium, bacteria of the genus Azospirillum, despite having limited ability to transfer $\mathrm{N}$ to the host plant, can transfer some of the nutrients needed to associated plants and/or produce growth-promoting substances, increasing rooting and yield (Bashan \& Bashan, 2010; Hungria, 2011; Pereira et al., 2015; Martins et al., 2018). Several studies have reported promising results regarding the use of inoculants based on Azospirillum spp. in maize crop (Silva et al., 2015; Skonieski et al., 2017; Martins et al., 2018).

Worldwide, most experiments to evaluate inoculation with Azospirillum brasilense in maize crop have shown increments in grain yield (Lana et al., 2012; Fukami et al., 2016). No Brasil, Hungria et al. (2010) inoculated selected species of Azospirillum brasilense and A. lipoferum in maize and wheat and found increments of 26 and $30 \%$ in their grain yields, respectively. Increments in maize yield were also observed by Araújo et al. (2014) with the inoculation of Azospirillum brasilense in the treatment of seeds, in the sowing furrow or through foliar application. However, positive responses of increase in grain yield due to the inoculation of seeds with Azospirillum brasilense are not always obtained, evidencing the need for research involving the use of these inoculants in association with nitrogen fertilization in maize crop, generating increments in grain yield and reduction in fertilizer consumption (Pandolfo et al., 2015; Skonieski et al., 2017; Martins et al., 2018).

In this context, due to the wide edaphoclimatic diversity existing in the various 
production environments of Brazil, studies in different regions are necessary to recommend the most appropriate management for maize crop in each situation. This occurs because factors such as soil type, sowing time, hybrid used and mode of application of the bacterium Azospirillum brasilense can affect the results and the management to be adopted in each region (Hungria et al., 2010).

The objective was to evaluate the effect of inoculation with Azospirillum brasilense, associated with top-dressing nitrogen fertilization, on the agronomic performance of maize.

\section{Material and Methods}

The experiment was conducted under field conditions, during the first season of 2013/14, in the experimental area of the São Paulo State University (UNESP), School of Agricultural and Veterinarian Sciences, Jaboticabal, SP, Brazil, near the coordinates of $21^{\circ} 14^{\prime} 33^{\prime \prime} \mathrm{S}$ latitude and $48^{\circ} 17^{\prime} 10^{\prime}$ W longitude, at an average altitude of 565 meters and Aw climate (humid tropical with rainy season in summer and dry season in winter), according to Köppen's classification.

The soil of the experimental area is classified as Latossolo Vermelho-Escuro eutrófico (Oxisol), of clayey texture (Embrapa, 2013), with a history of cultivation prior to succession/rotation with soybean (summer season) - maize (late offseason) - beans (winter/spring) - maize (summer season). Prior to maize sowing, soil samples were collected for analysis of chemical attributes in the $0.00-0.20 \mathrm{~m}$ layer, which showed the following results: $\mathrm{pH}\left(\mathrm{CaCl}_{2}\right)$ : 5.4; $\mathrm{OM}\left(\mathrm{g} \mathrm{dm}^{-3}\right)$ : 23; P resin $\left(\mathrm{mg} \mathrm{dm}^{-3}\right): 55 ; \mathrm{H}+\mathrm{Al} ; \mathrm{K} ; \mathrm{Ca} ; \mathrm{Mg} ; \mathrm{SB}$; CEC $\left(\mathrm{mmol}_{\mathrm{c}} \mathrm{dm}^{-3}\right): 31 ; 4.4 ; 37 ; 23 ; 64.4 ; 95.4$ and V: $68 \%$, respectively. Based on these results, it was decided not to perform liming, following the recommendations of Cantarella et al. (1997).

The experimental design was randomized blocks, in a split-plot scheme, with four replicates, and the variation factors (treatments) consisted of four managements of peat inoculant (MasterFix gramíneas ${ }^{\circledR}$ ) containing Azospirillum brasilense (AbV5 and AbV6 strains), associated with four top-dressing $\mathrm{N}$ doses.

Regarding the treatments related to inoculation with $A$. brasilense, (T0 - 0 viable cells ha ${ }^{-1}$, control; TC2 - $200 \times 10^{8}$ viable cells ha ${ }^{-1}$, applied in the seed box; TC3 $-400 \times 10^{8}$ viable cells $\mathrm{ha}^{-1}$, applied in the seed box; TS1 $600 \times 10^{8}$ viable cells ha-1, applied by previous seed treatment), in the treatments applied in the seed box, inoculation was performed directly in the seed reservoir of the seeder, with manual homogenization after application. The seeds were industrially treated with insecticide and fungicide, applying the TS1 treatment on the day of sowing, adding sugary solution at a concentration of $10 \%$, as recommended by Hungria (2011). The previous treatment of seeds (TS1) was prepared at a minimum concentration of $10^{8}$ cells of Azospirillum brasilense $\mathrm{g}^{-1}$ of peat inoculant. To increase its adhesion, $300 \mathrm{~mL}$ of the $10 \%$ sugary solution $(\mathrm{w} / \mathrm{v})$ were added to 50 $\mathrm{kg}$ of seeds. The sugary solution was applied to 
the seeds, followed by the peat inoculant, with drying in the shade for 15 minutes (Hungria, 2011). The same peat inoculant was used for all treatments evaluated (TC2, TC3 and TS1). As the peat inoculant had a concentration of $10^{8}$ cells of Azospirillum brasilense $\mathrm{g}^{-1}$ of inoculant, the treatments TC2, TC3 and TS1 received 200, 400 and $600 \mathrm{~g} \mathrm{ha}^{-1}$ of inoculant, in order to guarantee the pre-established doses mentioned above. For this, before the application of the treatments, the seeds were counted and weighed, calculating the amount of seeds $(\mathrm{kg})$ to be used per hectare. Thus, the amounts of inoculant to be applied in each box of the seeder for the treatments TC2 and TC3, and in the seeds for the TS1 treatment, were previously determined.

Seeds of single hybrid maize AG7088Pro2, with early cycle, intermediate size and main ear insertion height, pronounced stay-green, and orange semi-hard grains were used. The topdressing $\mathrm{N}$ doses $\left(0,60,120\right.$ and $180 \mathrm{~kg}$ of $\mathrm{N} \mathrm{ha}^{-}$ $\left.{ }^{1}\right)$ were applied after the emergence of the sixth fully developed leaf $\left(\mathrm{V}_{6}\right)$, using urea as source, which was distributed in a continuous strip at $0.20 \mathrm{~m}$ distance from the plants and incorporated at $0.10 \mathrm{~m}$ depth.

Each experimental subplot consisted of four rows spaced by $0.8 \mathrm{~m}$ with $5 \mathrm{~m}$ in length. The two central rows were considered as usable area, disregarding $0.5 \mathrm{~m}$ on each end. Soil tillage was conventional, using a plow harrow, deep plowing with chisel plow and harrowing. Fertilization at sowing consisted of $300 \mathrm{~kg}^{-1}$ of NPK 04-20-20 formulation $+\mathrm{Zn}$, corresponding to $12 \mathrm{~kg}$ of $\mathrm{N}$ $\mathrm{ha}^{-1}, 60 \mathrm{~kg}$ of $\mathrm{P}_{2} \mathrm{O}_{5} \mathrm{ha}^{-1}$ and $60 \mathrm{~kg}$ of $\mathrm{K}_{2} \mathrm{O} \mathrm{ha}{ }^{-1}$.

Sowing was performed in a mechanized way, on December 10, 2013, a time defined for the edaphoclimatic conditions of the São Paulo State as the first season (summer), with a depth of $3 \mathrm{~cm}$, at $0.8 \mathrm{~m}$ spacing between rows and sowing density of 6 seeds per meter of furrow. Maize seedlings emerged five days after sowing (DAS). There was no need for thinning, and a population of 62,500 plants ha-1 was obtained at harvest.

Invasive plants were controlled with application of metolachlor + atrazine herbicide in pre-emergence $\left(3.85 \mathrm{~L}\right.$ c.p. $\left.\mathrm{ha}^{-1}\right)$ and tembotrione (100.8 $\mathrm{g}$ a.i. ha ${ }^{-1}$ ) in post-emergence. Caterpillar control was performed with the use of biotechnology inserted through genetic improvement (AG7088Pro2 hybrid), and no chemical control of foliar diseases was necessary.

With the occurrence of a prolonged dry spell period, irrigation management was carried out using a conventional sprinkler system, with a 6-day interval, applying a water depth of 10$20 \mathrm{~mm}$ per irrigation event after the phenological stage $\mathrm{R}_{1}$ (Figure 1). During the experimental period, the average maximum and minimum temperatures were 31.0 and $19.1^{\circ} \mathrm{C}$, respectively. The total rainfall along the period was $491.5 \mathrm{~mm}$, with $261.8 \mathrm{~mm}$ during the reproductive stage of the crop. Rainfall during the experimental period was $48 \%$ lower than the normal annual average for the region $(952.1 \mathrm{~mm})$.

To monitor nutritional status and agronomic performance, during female flowering $\left(R_{1}\right)$, the central third of ten leaves below and opposite 


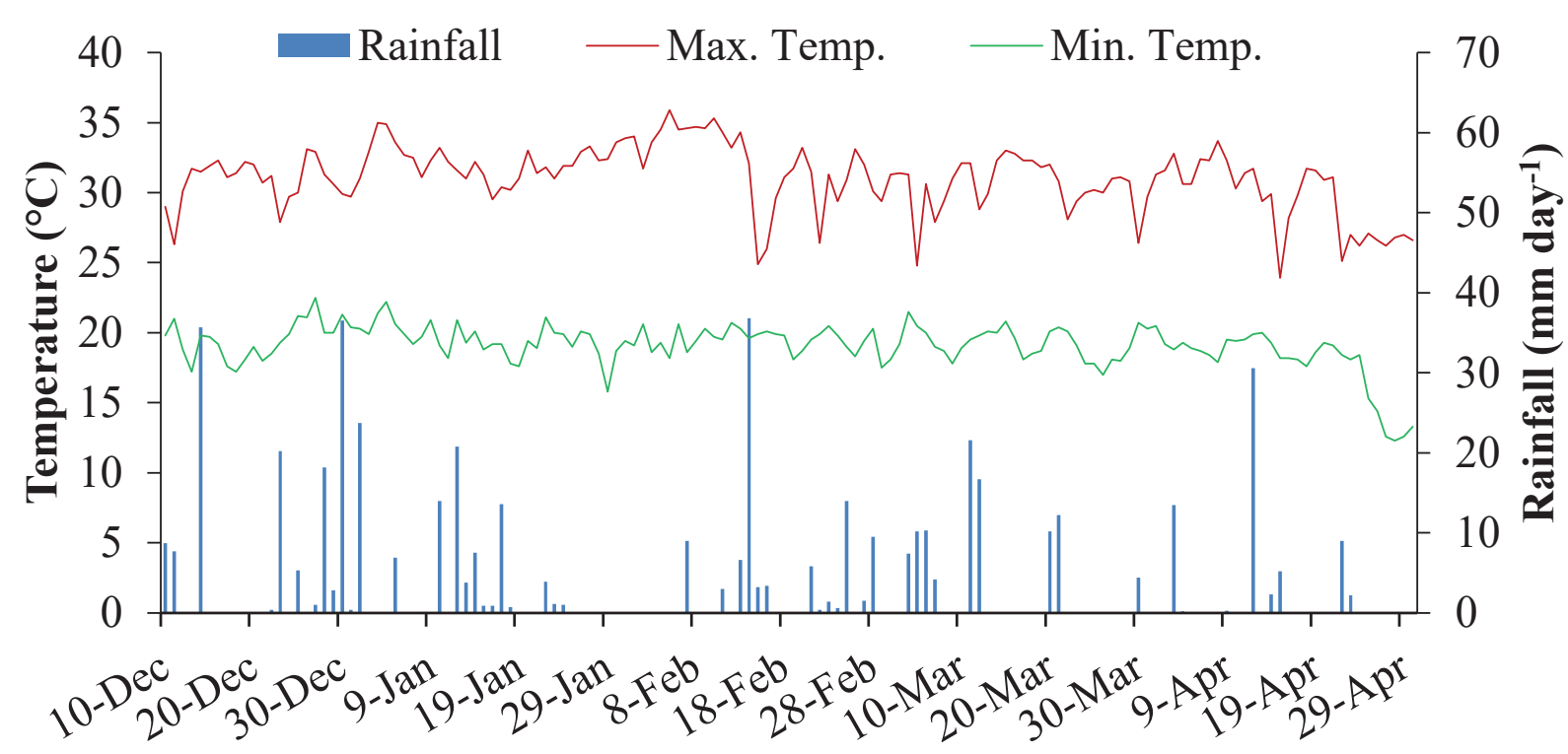

Date

Figure 1. Daily weather data during the experimental period from December 10, 2013 to April 30, 2014. Jaboticabal, São Paulo.

to the main ear was collected in ten plants per subplot; washed with running water and detergent at $1 \%$, dried in an oven with forced air circulation and renovation at $60-70{ }^{\circ} \mathrm{C}$, and then processed in a Wiley-type mill. After that, the $\mathrm{N}$ content was determined according to the method described by Malavolta et al. (1997). N content in the grains, as well as the total $\mathrm{N}$ content and accumulation in the dry matter of the plant, was determined using the same subsamples used to measure the harvest index. The results of the amount of dry matter produced and the respective total $\mathrm{N}$ contents were used to estimate the amount of the nutrient extracted by the crop, whereas the values of grain yield and the respective total $\mathrm{N}$ contents were used to estimate the respective $\mathrm{N}$ export in each subplot.

Upon completing physiological maturity
$\left(\mathrm{R}_{6}\right)$, the main ear insertion height was determined in 10 random plants. In this same phenological stage, ten ears representative of each subplot were collected to count the number of rows and grains in each row, estimating the number of grains per ear. 1000-grain weight was determined by collecting and counting 4 samples of 800 grains per experimental subplot and weighing with standardization of the results to $0.13 \mathrm{~kg} \mathrm{~kg}^{-1}$ on a wet basis, determined by the oven method at $105{ }^{\circ} \mathrm{C}+3{ }^{\circ} \mathrm{C}$ for 24 hours. Grain yield was obtained after manual harvesting and mechanized threshing of the ears present in the two central rows of each subplot, with determination of the water content in the grains, standardizing to $0.13 \mathrm{~kg} \mathrm{~kg}^{-1}$ on a wet basis. Harvest index was obtained at the stage 
$\mathrm{R}_{6}$ by the relation between the dry mass of grains and the total dry mass of shoots, in ten plants in the usable area of each subplot.

The data obtained were subjected to analysis of variance by $F$ test $(p<0.05)$ using the program Sisvar $^{\circledR}$ (Ferreira, 2011). When the quantitative factors $\mathrm{N}$ doses and the interaction of inoculation versus $\mathrm{N}$ doses were significant, a polynomial regression analysis was performed. Means were compared by Tukey test $(\mathrm{p}<0.05)$ only when the significance occurred for the qualitative factor inoculation management. Analysis of Pearson's linear correlation between maize grain yield and yield components was performed $(\mathrm{p}<0.05)$.

\section{Results and Discussion}

There were no differences between treatments for the variables main ear insertion height (MEIH), 1000-grain weight (1000GW) and harvest index (HI) (Table 1). The production components number of grain rows per ear (NGRE), number of grains per row (NGR) and number of grains per ear (NGE) were affected by the interaction of doses versus inoculation. For grain yield, there was a difference for the individual effects of $\mathrm{N}$ doses and inoculation.

In all types of inoculation with $A$. brasilense, NGRE data were described by second-degree equations as a function of the topdressing $\mathrm{N}$ doses (Figure 2a). The top-dressing $\mathrm{N}$ doses that ensured the maximum NGRE values for the types of inoculation control (T0), inoculation in the seed box with $200 \times 10^{8}$ viable cells ha ${ }^{-1}$ (TC2), inoculation in the seed box with $400 \times 10^{8}$ viable cells ha-1 ${ }^{-1}$ (TC3) and inoculation by previous treatment of seeds (TS1), equal to $289,96,117$ and $155 \mathrm{~kg} \mathrm{ha}^{-1}$, respectively. Thus, it was observed that only for the control management the $\mathrm{N}$ dose that led to the maximum

Table 1. Analysis of variance (F Test) for main ear insertion height (MEIH), number of grain rows per ear (NGRE), number of grains per row (NGR), number of grains per ear (NGE), 1000-grain weight $(1000 \mathrm{GW})$, grain yield (GY) and harvest index (HI) of maize (Zea mays L.) plants as a function of inoculation with Azospirillum brasilense and top-dressing $\mathrm{N}$ doses

\begin{tabular}{cccccccc}
\hline S.V. & MEIH & NGRE & NGR & $\begin{array}{c}\text { NGE } \\
\text { F value }\end{array}$ & $1000 G W$ & GY & HI \\
I & $0.63^{\text {ns }}$ & $9.43^{* *}$ & $13.30^{* *}$ & $11.78^{* *}$ & $0.53^{\text {ns }}$ & $18.60^{* *}$ & $0.29^{\text {ns }}$ \\
N & $1.91^{\text {ns }}$ & $7.47^{* *}$ & $20.33^{* *}$ & $49.05^{* *}$ & $0.14^{\text {ns }}$ & $21.35^{* *}$ & $0.62^{\text {ns }}$ \\
I x N & $0.44^{\text {ns }}$ & $2.17^{*}$ & $2.51^{*}$ & $2.32^{*}$ & $1.10^{\text {ns }}$ & $0.45^{\text {ns }}$ & $0.84^{\text {ns }}$ \\
\hline CV (\%) I & 8.2 & 2.3 & 3.2 & 2.9 & 3.0 & 4.1 & 5.2 \\
N & 4.7 & 4.3 & 3.9 & 4.1 & 3.4 & 5.9 & 4.2 \\
\hline
\end{tabular}

S.V. (Source of variation); Inoculation (I); Top-dressing N (N); ** $(\mathrm{p}<0.01) ; *(\mathrm{p}<0.05) ;{ }^{\text {ns }}$ (not significant), respectively by $\mathrm{F}$ test. 

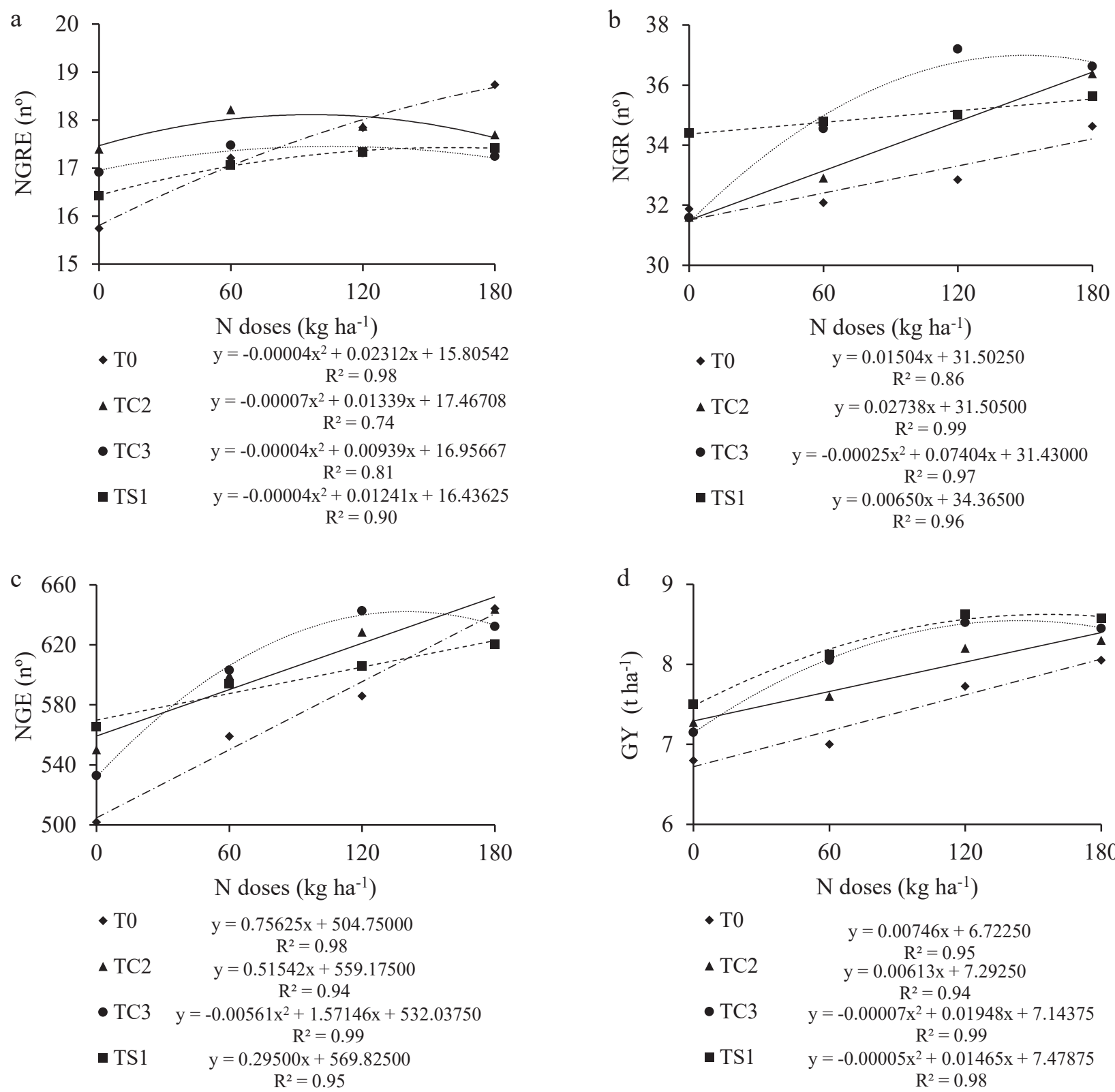

Figure 2. Regression analysis for the managements of inoculation with Azospirillum brasilense as a function of top-dressing nitrogen for the variables number of grain rows per ear (NGRE - a), number of grains per row (NGR - b), number of grains per ear (NGE - c) and grain yield (GY - d) of maize crop. 
value of NGRE was above the $\mathrm{N}$ doses tested.

Regarding NGR and NGE, the fits of the inoculation types data were different, with the managements T0, TC2 and TS1 showing increasing linear fit as a function of the topdressing $\mathrm{N}$ doses and the TC3 management showing a quadratic fit as a function of the $\mathrm{N}$ doses (Figure 2b and 2c). The maximum values of NGR and NGE for the TC3 inoculation management were obtained with $\mathrm{N}$ doses of 148 and $141 \mathrm{~kg} \mathrm{ha}^{-1}$, respectively.

In GY, the data of the TC3 and TS1 inoculation managements were described by second-degree equations and, for the T0 and TC2 managements, the data were described by increasing linear equations (Figure 2d). The maximum GY values for the TC3 (8.50 $\left.\mathrm{t} \mathrm{ha}^{-1}\right)$ and TS1 (8.55 tha-1) managements were obtained with $\mathrm{N}$ doses of 139 and $147 \mathrm{~kg} \mathrm{ha}^{-1}$, respectively. In addition, through the equations generated, it was observed that the GY of the inoculation managements T0, TC2, TC3 and TS1, without top-dressing $\mathrm{N}$ fertilization, was 6.72, 7.29, 7.14 and $7.48 \mathrm{tha}^{-1}$, respectively.

This shows that, on average, the managements with inoculation of $A$. brasilense increased maize GY by $8.7 \%$ in the absence of top-dressing $\mathrm{N}$ fertilization. In addition, it was observed that the application of $A$. brasilense reduces the demand for top-dressing $\mathrm{N}$ fertilization in maize to obtain maximum yields, because the maximum GY in the control treatment was obtained with a top-dressing $\mathrm{N}$ dose higher than that of the treatments that had inoculation with $A$. brasilense.

In relation to maize nutrition regarding $\mathrm{N}$, there were significant interactions between inoculation and top-dressing $\mathrm{N}$ doses for all variables, except for $\mathrm{N}$ export (Table 2). For the $\mathrm{N}$ export, there were differences for the simple effects studied (inoculation and $\mathrm{N}$ doses).

The $\mathrm{N}$ content in the leaves did not have variation model as a function of the top-dressing $\mathrm{N}$ doses for the TC2 inoculation management, showing a mean value of $24.4 \mathrm{~g} \mathrm{~kg}^{-1}$ of $\mathrm{N}$ (Figure $3 \mathrm{a})$. For the other inoculation managements, the data were described by quadratic equations, with an increasing equation for the T0 management and decreasing equations for the TC3 and TS1 managements. In the absence of topdressing $\mathrm{N}$ fertilization, it was observed that the managements with the presence of inoculation of A. brasilense led to leaf $\mathrm{N}$ content higher than that found in the control without inoculation, indicating the beneficial effect of diazotrophic bacteria in increasing $\mathrm{N}$ nutrition of maize.

For the $\mathrm{N}$ content in the grains, only the treatment without inoculation with $A$. brasilense did not show a significant model for the variation of this variable as a function of the top-dressing $\mathrm{N}$ doses (Figure 3b). The managements with inoculation were described by quadratic equations as a function of the top-dressing $\mathrm{N}$ doses. This same pattern was observed for the $\mathrm{N}$ content in the shoots, with the inoculated management data described by quadratic equations and the control management without inoculation not described by any tested model. 
Table 2. Analysis of variance for the total $\mathrm{N}$ content in leaves (NCL), grains (NCG) and shoots (NCS), $\mathrm{N}$ extraction (NEXT) and N export (NEXP) of maize (Zea mays L.) plants as a function of inoculation with Azospirillum brasilense and top-dressing $\mathrm{N}$ doses.

\begin{tabular}{cccccc}
\hline S.V. & NCL & NCG & NCS & NEXT & NEXP \\
\hline I & $5.99^{*}$ & $0.32^{\text {ns }}$ & $2.0^{\text {ns }}$ & $1.56^{\text {ns }}$ & $6.86^{*}$ \\
N & $15.83^{* *}$ & $0.82^{\text {ns }}$ & $1.42^{\text {ns }}$ & $9.87^{* *}$ & $11.81^{* *}$ \\
I x N & $10.97^{* *}$ & $2.76^{*}$ & $4.30^{* *}$ & $2.88^{*}$ & $2.04^{\text {ns }}$ \\
\hline CV (\%) I & 7.3 & 6.6 & 11.2 & 6.6 & 6.3 \\
N & 5.8 & 5.3 & 9.9 & 9.5 & 8.2 \\
\hline
\end{tabular}

S.V. (Source of variation); Inoculation (I); Top-dressing N (N); ${ }^{* *}(\mathrm{p}<0.01) ; *(\mathrm{p}<0.05) ;{ }^{\text {ns }}$ (not significant), respectively by $\mathrm{F}$ test.

Regarding $\mathrm{N}$ extraction, the data of the TC2 and TC3 inoculation managements as a function of the top-dressing $\mathrm{N}$ doses were described by linear and quadratic models, respectively, while the data of the T0 and TS1 managements were not described by any tested model (Figure 3d). The maximum value of $\mathrm{N}$ extraction by TC3 management was $109 \mathrm{~kg} \mathrm{ha}^{-1}$ of $\mathrm{N}$. In the case of $\mathrm{N}$ export, the data of management with the presence of inoculation with $A$. brasilense were described by quadratic equations as a function of top-dressing $\mathrm{N}$ fertilization, with maximum values obtained for the managements TC2, TC3 and TS1 at top-dressing $\mathrm{N}$ doses of 187, 125 and $106 \mathrm{~kg}$ ha $^{-1}$ (Figure 3d). The control management without inoculation was described by the linear equation.

It was observed that the managements TC3 and TS1 stood out from the others for grain yield, with maximum yields close to the top-dressing
$\mathrm{N}$ dose of $140 \mathrm{~kg} \mathrm{ha}^{-1}$. For the managements TC2 and the control without inoculation (T0), it was not possible to obtain the maximum point of yield, because the models generated for GY in these managements were linear. Thus, the managements with inoculation TC3 and TS1 showed the capacity to reduce the top-dressing $\mathrm{N}$ dose to obtain the maximum GY, so these managements of inoculation with $A$. brasilense were the most recommended for maize.

By comparing the linear models of treatments $\mathrm{T} 0$ and $\mathrm{TC} 2$, it was observed that for the non-inoculated management there is an increase of $0.45 \mathrm{t} \mathrm{ha}^{-1}$ in GY for every 60 $\mathrm{kg} \mathrm{ha}^{-1}$ of top-dressing $\mathrm{N}$, while for the TC2 management this increment is $0.37 \mathrm{tha}^{-1}$. This confirms the reduction in the use of top-dressing $\mathrm{N}$ when maize is inoculated with $A$. brasilense, because the management without inoculation 


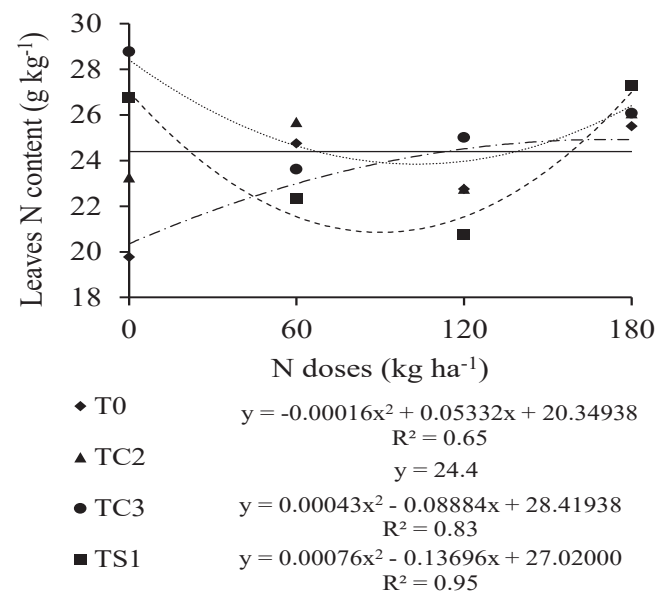

$\mathrm{c}$

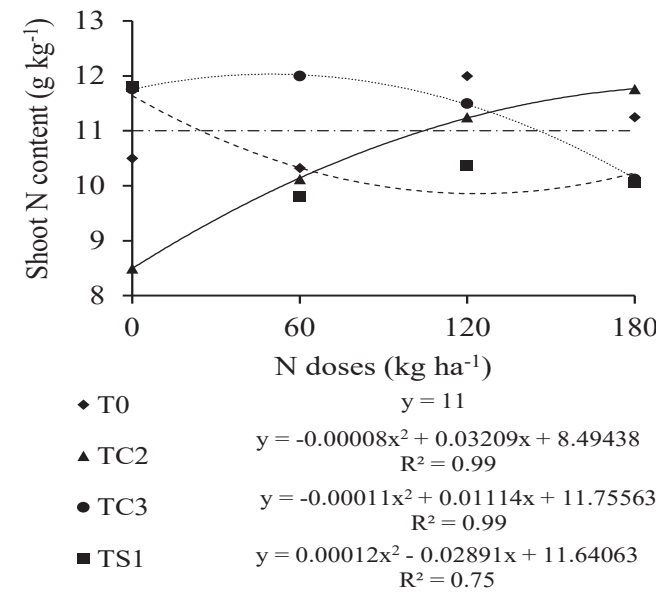

$\mathrm{b}$

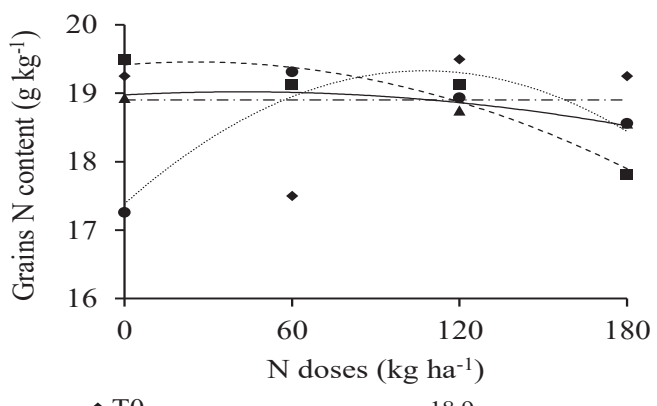

- T0 $\quad \mathrm{y}=18.9$

$\Delta$ TC2 $y=-0.00003 x^{2}+0.00219 x+18.97500$

$\mathrm{R}^{2}=0.84$
- TC3 $\mathrm{y}=-0.0002 \mathrm{x}^{2}+0.0362 \mathrm{x}+17.384$
$\mathrm{R}^{2}=0.87$

- TS1 $1 \quad \mathrm{y}=-0.00007 \mathrm{x}^{2}+0.00328 \mathrm{x}+19.41563$

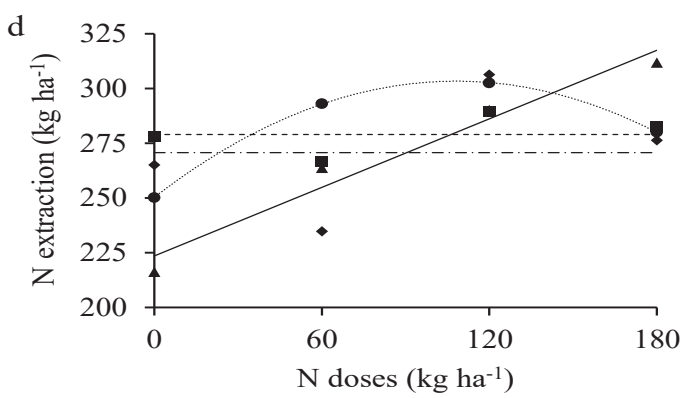

- T0 $\quad \mathrm{y}=270.6$

$\triangle \mathrm{TC} 2 \quad \mathrm{y}=0.52155 \mathrm{x}+223.52340$

- TC3

$y=-0.00453 x^{2}+0.98063 x+250.26438$

- TS1

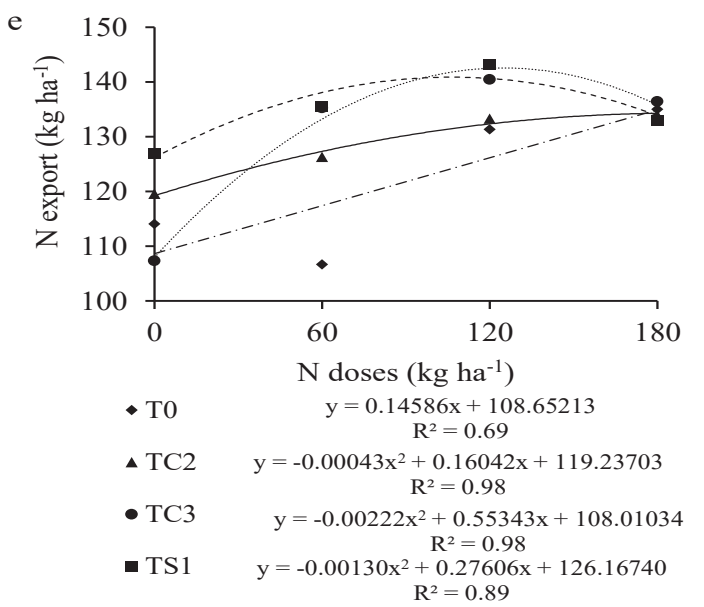

Figure 3. Regression analysis for the managements of inoculation with Azospirillum brasilense as a function of top-dressing nitrogen doses for the variables $\mathrm{N}$ content in leaves (a), $\mathrm{N}$ content in grains (b), $\mathrm{N}$ content in shoots (c), $\mathrm{N}$ extraction (d) and $\mathrm{N}$ export (e) for maize crop. 
(T0) led to a greater increase in GY with the increase in top-dressing $\mathrm{N}$ than the management with inoculation in the seed box with $200 \times 10^{8}$ viable cells per ha (TC2).

Among the managements with inoculation of A. brasilense (TC2, TC3 and TS1), it was verified that TC3 and TS1 had similar values of GY and these were higher than that of the TC2 management. Thus, the recommendation of $A$. brasilense inoculation can be made both with the treatment in the seed box of the seeder, with $400 \times 10^{8}$ viable cells per ha (TC3) and in the previous treatment of seeds (TS1). The higher yields of these treatments, compared to that of TC2, were probably due to the lower amount of bacteria used in the TC2 management, not promoting higher growth in maize plants.

In general, the average observed in grain yield was low, compared to the potential of the crop at the time the experiment was conducted. These results can be explained by the intense dry spell period that occurred during cultivation, coinciding with the reproductive period of the plants, that is, between $\mathrm{V}_{\mathrm{T}}$ and $\mathrm{R}_{1}$ (Figure 1). Although the experiment was irrigated from the phenological stage $\mathrm{R}_{1}$, the water deficit caused at the beginning of the reproductive stage of the crop, between $\mathrm{V}_{\mathrm{T}}$ and $\mathrm{R}_{1}$, prevented the hybrid from expressing its high production potential. On the other hand, Silva et al. (2015) observed that moderate water deficits before flowering favor the expression of the effect of inoculation on maize grain yield, which can be observed in the present study. This occurs because the application of $A$. brasilense tends to increase root growth, thus reducing the effect of water deficit on plants inoculated with the bacterium (Hungria et al., 2010; Leite et al., 2019; Zeffa et al., 2019). Leite et al. (2019), evaluating the inoculation of $A$. brasilense in Marandu grass, concluded that inoculation with the bacterium reduces the negative effect of water deficit on the dry mass production of this forage.

The production component that most explained the increase in yield as a function of inoculation managements and the increase in top-dressing $\mathrm{N}$ doses was the number of grains per row (NGR). The regression analyses of the production components (Figure 2) showed that the variation of inoculation managements for NGR was similar to the variation of the same managements for GY, with inoculated managements leading to the highest values for the two variables. For the number of grain rows per ear (NGRE), there was high variation between the managements, with the control without inoculation leading to higher values of NGRE from the top-dressing $\mathrm{N}$ dose of $120 \mathrm{~kg}$ $\mathrm{ha}^{-1}$. This is confirmed by Pearson's correlation analysis of these two production components with GY, in which NGRE has a correlation of 0.43 with GY and NGR has a correlation of 0.90 . Among the production components, NGR shows greater variation as a function of the managements adopted, while NGRE has greater genotypic variation (Chen et al., 2017; Panison et al., 2019). This explains the fact that NGR is the component with the highest correlation with GY. 
For the 1000-grain weight, it is observed that the variation for this component usually only occurs as a function of water deficit, reducing $1000 \mathrm{GW}$ (Ben et al., 2019).

Regarding the total $\mathrm{N}$ content in the leaves, in most treatments the values obtained were lower than those considered adequate (27 to 35 $\mathrm{g} \mathrm{kg}^{-1}$ ) by Cantarella et al. (1997). As $\mathrm{N}$ is highly dependent on the mass flow for its absorption (Oliveira et al. 2010), the dry spell period that occurred may have interfered with this variable. However, in the control without top-dressing $\mathrm{N}$ application, the inoculated managements TC3 and TS1 led to values above the ideal minimum for maize (Figure 3a), confirming that $A$. brasilense improves the physiological state of the crop in terms of $\mathrm{N}$, promoting an increase in leaf $\mathrm{N}$ content. In addition, the reduction in leaf $\mathrm{N}$ content with the increase in top-dressing $\mathrm{N}$ dose for these treatments may have occurred due to the dilution of $\mathrm{N}$ from the increase in dry mass production by the crop when inoculated with $A$. brasilense.

Regarding the total $\mathrm{N}$ content in the grains, quadratic behavior was observed for the managements TC2, TC3 and TS1, with maximum values obtained at $\mathrm{N}$ doses of 27, 24 and $91 \mathrm{~kg}$ $\mathrm{ha}^{-1}$, respectively (Figure 3 ). Regarding the $\mathrm{N}$ content in the shoots of maize, constant values were observed in the absence of inoculation (T0), regardless of the top-dressing $\mathrm{N}$ dose, while the maximum values were observed at the estimated $\mathrm{N}$ doses of 178 and $56 \mathrm{~kg} \mathrm{ha}^{-1}$ for the TC2 and TC3 managements, respectively (Figure 3c). In the case of TS1, there was a reduction in the $\mathrm{N}$ content in the shoots from the top-dressing $\mathrm{N}$ application of $60 \mathrm{~kg} \mathrm{ha}^{-1}$, with minimum value obtained at the estimated $\mathrm{N}$ dose of $145 \mathrm{~kg} \mathrm{ha}^{-1}$ (Figure 3c).

In general, it was verified that the $\mathrm{N}$ extraction by maize subjected to inoculation with $A$. brasilense was superior to that found in the management in which the crop was not inoculated (T0), either in the overall mean of TS1 management or from the top-dressing $\mathrm{N}$ doses of $30 \mathrm{~kg} \mathrm{ha}^{-1}$ and $90 \mathrm{~kg} \mathrm{ha}^{-1}$ for the TC3 and TC2 managements, respectively. This demonstrates greater ability of maize to extract nutrients from the soil when inoculated with the bacterium. For the $\mathrm{N}$ export, the managements with inoculation of $A$. brasilense led to the highest values. This was due to the higher grain yields of these treatments because, for the $\mathrm{N}$ content in the grains, there were no relevant differences between the managements.

Thus, more sustainable agricultural managements, such as inoculation of maize with A. brasilense, can be adopted to reduce the use of $\mathrm{N}$ fertilizers. In addition to reducing production costs by reducing $\mathrm{N}$ doses, inoculation with the bacterium generates greater revenue to the producer, due to the increase in maize yield, thus generating greater economic and environmental sustainability, since the production of mineral nitrogen requires the consumption of fossil fuels and substances with potential for environmental contamination. 


\section{Conclusions}

Inoculation of maize with Azospirillum brasilense increases the agronomic performance of the crop, increasing grain yield and reducing the need for top-dressing $\mathrm{N}$ to obtain maximum grain yield. Managements with inoculation in the seed box of the seeder with $400 \times 10^{8}$ viable cells per ha (TC3) and inoculation in previous seed treatment with $400 \times 10^{8}$ viable cells per ha (TS1) are the most recommended for maize.

\section{References}

ARAÚJO, R. M.; ARAÚJO, A. S. F.; NUNES, L. A. P. L.; FIGUEIREDO, M. V. B. Resposta do milho verde à inoculação com Azospirillum brasiliense e níveis de nitrogênio. Ciência Rural, Santa Maria, v. 44, n. 9, p. 1556-1560, 2014. DOI: 10.1590/0103-8478cr20130355.

BALDANI, J. I.; CARUSO, L.; BALDANI, V. L. D.; GOI, S. R.; DÖBEREINER, J. Recent advances in bnf with non-legume plants. Soil Biology and Biochemistry, Oxford, v. 29, n. 5-6, p. 911-922, 1997. DOI: 10.1016/S00380717(96)00218-0.

BASHAN, Y.; BASHAN, L. E. How the plant growth-promoting bacterium Azospirillum promotes plant growth - a critical assessment. Advances in Agronomy, San Diego, v. 108, p. 77-136, 2010. DOI: 10.1016/S00652113(10)08002-8.
BEN, L. H.; PEITER, M. X.; ROBAINA, A. D.; KIRCHNER, J. H.; MEZZOMO, W.; PIMENTA, B. D. Agronomic performance of maize hybrids under supplemental irrigation depths. Revista Brasileira de Engenharia Agrícola e Ambiental, Campina Grande, v. 23, n. 7, p. 524531, 2019. DOI: 10.1590/1807-1929/agriambi. v23n7p524-531.

CANTARELlA, H.; DUARTE, A. P. Manejo da fertilidade do solo para a cultura do milho. In: GALVÃO, J.C.C.; MIRANDA, G.V. (Eds.). Tecnologias de produção de milho. Viçosa: Editora UFV, 2004. p. 139-182.

CANTARELLA, H.; RAIJ, B. V.; CAMARGO, C. E. O. Adubação de cereais. In: RAIJ, B. V.; CANTARELlA, H.; QUAGGIO, J. A.; FURLANI, A. M. C. (Ed.). Recomendações de adubação e calagem para o Estado de São Paulo. 2.ed. Campinas: Instituto Agronômico, 1997. p. 43-50. (IAC. Boletim técnico, 100).

CHEN, K.; CAMBERATO, J. J.; VYN, T. J. Maize grain yield and kernel component relationships to morphophysiological traits in commercial hybrids separated by four decades. Crop Science, Hoboken, v. 57, n. 3, p. 16411657, 2017. DOI: 10.2135/cropsci2016.06.0540.

CONAB - Companhia Nacional de Abastecimento. Acompanhamento da safra brasileira - grãos, nono levantamento, safra 2017/18. Disponível em: <http://www.conab. 
gov.br>01 Jul. 2018.

FERREIRA, D. F. Sisvar: a computer statistical analysis system. Ciência e Agrotecnologia, Lavras, v. 35, n. 6, p. 1039-1042, 2011. DOI: 10.1590/S1413-70542011000600001.

FORNASIERI FILHO, D. Manual da cultura do milho. 1.ed. Jaboticabal: FUNEP, 2007. 576p.

FUKAMI J.; NOGUEIRA, M. A; ARAUJO, R. S.; HUNGRIA, M. Accessing inoculation methods of maize and wheat with Azospirillum brasilense. AMB Express, Heidelberg, v. 6, n. 3, p. 1-13, 2016. DOI: 10.1186/s13568-015-0171-y.

HANASHIRO, R.; MINGOTTE, F. L. C.; FORNASIERI FILHO, D. Desempenho fenológico, morfológico e agronômico de cultivares de milho em Jaboticabal-SP. Científica, v. 41, n. 2, p. 226-234, 2013.

HUNGRIA, M. Inoculação com Azospirillum brasilense: inovação em rendimento a baixo custo. 2.ed. Londrina: Embrapa Soja, 2011. 36p. (Embrapa Soja. Documentos, 325).

HUNGRIA, M.; CAMPO, R. J.; SOUZA, E. M.; PEDROSA, F. O. Inoculation with selected strains of Azospirillum brasilense and $A$. lipoferum improves yields of maize and wheat in Brazil. Plant and Soil, Dordrecht, v. 331, n. 1-2, p. 413-425, 2010. DOI: 10.1007/s11104-0090262-0.
LANA, M. C.; DARTORA, J.; MARINI, D.; HANN, J. E. H. Inoculation with Azospirillum, associated with nitrogen fertilization in maize. Revista Ceres, Viçosa,v. 59,n.3,p.399-405, 2012. DOI: 10.1590/S0034-737X2012000300016.

LEITE, R. D. C.; SANTOS, J. G.; SILVA, E. L.; ALVES, C. R.; HUNGRIA, M.; LEITE, R. D. C.; SANTOS, A. C. Productivity increase, reduction of nitrogen fertiliser use and droughtstress mitigation by inoculation of Marandu grass (Urochloa brizantha) with Azospirillum brasilense. Crop and Pasture Science, Clayton, v. 70, n. 1, p. 61-67, 2019. DOI: 10.1071/ CP18105.

MALAVOLTA, E.; VITTI, G. C.; OLIVEIRA, S. A. Avaliação do estado nutricional das plantas: princípios e aplicações. 2.ed. Piracicaba: Potafós, 1997. 319p.

MARTINS, M. R.; JANTALIA, C. P.; REIS, V. M.; DÖWICH, I.; POLIDORO, J. C.; ALVES, B. J. R.; BODDEY, R. M.; URQUIAGA, S. Impact of plant growth-promoting bacteria on grain yield, protein content, and urea ${ }^{-15} \mathrm{~N}$ recovery by maize in a Cerrado Oxisol. Plant and Soil, Dordrecht, v. 422, n. 1-2, p. 239-250, 2018. DOI: 10.1007/s11104-017-3193-1.

OLIVEIRA, E. M. M.; RUIZ, H. A.; ALVAREZ, V.; HUGO, V.; FERREIRA, P. A.; COSTA, F. O.; ALMEIDA, I. C. C. Nutrient supply by mass flow and diffusion to maize plants in response to 
soil aggregate size and water potential. Revista Brasileira de Ciência do Solo, Viçosa, v. 34, n. 2, p. 317-328, 2010. DOI: 10.1590/S010006832010000200005.

PANDOLFO, C. M.; VOGT, G. A.; BALBINOT JÚNIOR, A. A.; GALLOTTI, G. J. M.; ZOLDAN, S. R. Desempenho de milho inoculado com Azospirillum brasiliense associado a doses de nitrogênio em cobertura. Agropecuária Catarinense, Florianópolis, v. 27, n. 3, p. 94-99, 2015

PANISON, F.; SANGOI, L.; DURLI, M. M.; LEOLATO, L. S.; COELHO, A. E.; KUNESKI, H. F.; LIZ, V. O. D. Timing and splitting of nitrogen side-dress fertilization of early corn hybrids for high grain yield. Revista Brasileira de Ciência do Solo, Viçosa, v. 43, 2019. DOI: 10.1590/18069657rbcs20170338.

PEREIRA, L. M.; PEREIRA, E. M.; REVOLTI, L. T. M.; ZINGARETTI, S. M.; MÔRO, G. V. Seed quality, chlorophyll content index and leaf nitrogen levels in maize inoculated with Azospirillum brasilense. Revista Ciência Agronômica, Fortaleza, v. 46, n. 3, p. 630-637, 2015. DOI: 10.5935/1806-6690.20150047.
SILVA, A. G.; DUARTE, A. P.; PIEDADE, R. C.; COSTA. H. P.; MEIRELES, K. G. C.; BORGES, L. P. Inoculação de sementes de milho safrinha com Azospirillum e aplicação de nitrogênio em cobertura. Revista Brasileira de Milho e Sorgo, Sete Lagoas, v. 14, n. 3, p. 358-370, 2015. DOI: 10.18512/1980-6477/rbms.v14n3p358-370.

SKONIESKI, F. R.; VIÉGAS, J.; MARTIN, T. N.; NÖRNBERG, J. L.; MEINERZ, G. R.; TONIN, T. J.; BERNHARD, P.; FRATA, M. T. Effect of seed inoculation with Azospirillum brasilense and nitrogen fertilization rates on maize plant yield and silage quality. Revista Brasileira de Zootecnia, Viçosa, v. 16, n. 9, p. 722-730, 2017. DOI: $10.1590 / \mathrm{s} 1806-92902017000900003$.

ZEFFA, D. M.; PERINI, L. J.; SILVA, M. B.; SOUSA, N. V.; SCAPIM, C. A.; OLIVEIRA, A. L. M.; GONCALVES, L. S. A. Azospirillum brasilense promotes increases in growth and nitrogen use efficiency of maize genotypes. PloS one, San Francisco, v. 14, n. 4, p. e0215332, 2019. DOI: 10.1371/journal.pone.0215332. 